Встановлено раціональні режими ферментативної деструкціі автолізату композииї молочнокислих бактерій методом математичного планування багатофакторних експериментів. Досліджено ферментолізат, отриманий за раціональних умов деструкції, на предмет наявності у його складі імунотропних сполук - продуктів деградації пептидоглікану клітинних стінок бактерій. Методами гель-хроматографіï та IЧ-спектроскопії доведено, що у складі ферментолізату містяться низькомолекулярні пептиди, які можна віднести до сполук мурамилпептидного ряду, що володіють потужним імунотропним ефектом

Ключові слова: біомаса, молочнокислі бактерії, автоліз, ферментативний гідроліз, панкреатин, пептидоглікан, мурамилпептид, імунотропні властивості, математичне моделювання

Установлены рациональные режимы ферментативной деструкции автолизата композиции молочнокислых бактерий методом математического планирования многофакторных экспериментов. Исследован ферментолизат, полученный при рациональных условий деструкции, на предмет наличия в его составе иммунотропных соединений - продуктов деградации пептидогликана клеточных стенок бактерий. Методами гель-хроматографии и ИК-спектроскопии доказано, что в составе ферментолизата содержатся низкомолекулярные пептиды, которые можно отнести к соединениям мурамилпептидного ряда, обладающих мощным иммунотропным әффектом

Ключевые слова: биомасса, молочнокислые бактерии, автолиз, ферментативный гидролиз, панкреатин, пептидогликан, мурамилпептиды, иммунотропные свойства, математическое моделирование

$$
\square
$$

ㅁ
Bacteria are the main activators of the immune system in humans and animals' organism. The existence of innate immunity is based on recognition of microbial ligands by immunocompetent cell receptors. Signals for the start of the immune response are not living bacteria, and their fragments, or products of vital activity [1].
UDC 602.4:[577.15:577.114.4]:635.342

DOI: $10.15587 / 1729-4061.2018 .120877$

\section{DETERMINATION OF THE} ENZYME DESTRUCTION RATIONAL MODE OF BIOMASS AUTOLYSATE OF LACTIC ACID BACTERIA

\author{
A. Kapustian
}

PhD, Associate Professor Department of Food Chemistry* E-mail: foodchem.onaft@gmail.com

N. Cherno

Doctor of Technical Sciences, Professor, Head of Department Department of Food Chemistry*

E-mail: cherno.onaft@gmail.com

G. St a n k e vi ch

Doctor of Technical Sciences, Professor, Head of Department Department of Technology for Storage of Grain*

E-mail: georgii.stn@gmail.com

I. Kolomi i e t s

$\mathrm{PhD}$, Associate Professor

Department of Normal and

Pathological Physiology named after S. V. Stoianovskiy**

E-mail : kolomieciryna@gmail.com

O. Ma t s j u k

PhD, Assistant

Department of Normal and

Pathological Physiology named after S. V. Stoianovskiy **

E-mail: matsjuk.oksana@gmail.com

L. Mus i y

$\mathrm{PhD}$, Senior Lecturer

Department of Technology of milk and milk products**

E-mail: musiyluba@ukr.net

I. S I y v k a

$\mathrm{PhD}$, Assistant

Department of Technology of milk and milk products**

E-mail: slyvka.88@ukr.net

*Odessa National Academy of Food Technologies

Kanatna str., 112, Odessa, Ukraine, 65039

**Stepan Gzhytskyi National University of Veterinary

Medicine and Biotechnologies Lviv

Pekarska str., 50, Lviv, Ukraine, 79010

Objects for recognition by the innate immune system are the structural components of peptidoglycans of bacteria cell walls. These are compounds of the muramyl peptide series with a molecular weight of up to $1500 \mathrm{Da}$ [2]. Therefore, the destruction of the peptidoglycan of bacterial cells in order to obtain the active substances of the muramyl peptide series, which are easier to digest, enter into biochemical processes and stimulate the 
body's immune response to external pathogenic factors is expedient.

The use of immunological agents based on lysates of bacterial origin is becoming increasingly widespread in medical practice. This tendency is caused in the first place by the fact that in the progressive amount there are antibiotic-resistant strains of pathogenic microorganisms. One of the effective methods of combating them is the use of drugs based on the products of destruction of peptidoglycans of bacteria cell walls.

It should be noted that the nutritional support of the population suffering from disorders of the immune system is very important. Therefore, the development of nutritional ingredients and dietary supplements based on degradation products of bacterial peptidoglycans is very relevant.

\section{Literature review and problem statement}

The minimal repeating fragment of peptidoglycan is muramyl dipeptide (MDP). MDP has all necessary properties for pathogen-associated molecular structures, which are manifested in the stimulation of innate immunity and the ability to form protection against microbial infectious agents [3, 4]. MDP is recognized by the intracellular Nod2-like receptors of the body, initiates a signaling cascade of reactions, which leads to the synthesis of proinflammatory cytokines by immunocompetent cells and the activation of mechanisms of immunological protection of the organism [5].

There are a number of immunotropic pharmacological agents based on the products of degradation of bacteria cell walls, i.e. lysates, which are widely used in medical practice. There are immunomodulators of microbial origin on the basis of microorganisms lysates, for example, "Bronchommunal", "Immudon", "IRS-19", "Posterizan", "Lyasten". There are also a number of synthetic immunotropic agents of the peptide series, for example, "Licopid", active ingredient glucosaminylmuramyl dipeptide (GMDP), "Romurtid", "Murabutyd" [6-8].

In the world market, there are almost no immunotropic food ingredients and dietary supplements based on bacterial lysates that would be appropriate to use as a nutritional support in the complex treatment of the population suffering from disorders of the immune system. The interaction of these compounds with food components is limited to hydrophilic-hydrophobic bonds, which easily decompose in the process of digestion and absorption.

The following methods of cell destruction can be used for the production of bacterial lysates: physical, mechanical, chemical, biological and combined [9]. Autolytic processes can lead to partial disintegration of cells [10], since most bacteria synthesize a group of enzymes known as autolysins which are able to hydrolyze peptidoglycan of their own cell wall. Typically, physical or autolytic disintegration of microbial cells leads to an irreversible violation of their anatomical integrity [11]. In order to produce glycopeptide low molecular weight products of a regular structure, chemical and enzymatic methods of destruction are usually used [12-14]. The enzymatic methods of hydrolysis of peptidoglycans of bacteria cell walls are milder compared with chemical ones. As a rule, fermentolysis is carried out at physiological $\mathrm{pH}$ values of the medium and temperature.
The development of immunotropic food ingredients and dietary supplements based on the products of degradation of the cell walls of lactic acid bacteria (LAB) is promising. LAB have the "GRAS" status (Generally Recognized As Safe), in addition, a considerable cultivation experience has been accumulated to obtain eubiotic agents [15-18].

The use of combined methods of degradation of LAB biomass in order to obtain fragments of their cell walls was investigated in a number of studies.

Thus, in [12], the hydrolysis of Lactobacillus bulgaricus with sequentially treatment with pepsin, lysozyme and ultrasound was performed. In the paper [13], the hydrolysate of L.acidophilus $U-2505$ was obtained by the thermoacid method. There is also a method for obtaining a product [14] containing glycopeptides, which involves the production of L. bulgaricus biomass in special nutrient media, biomass treatment with trypsin, biomass disintegration with ultrasound, biomass re-treatment with trypsin and pepsin, centrifugation, lysozyme hydrolysis, and chromatography.

Aggressive components [13], large number of technological operations $[12,14]$, costly reagents, enzyme drugs $[12]$ and purification methods $[6,14]$ are used in most of the existing works for obtaining the structural components of peptidoglycans of bacteria cell walls.

In this work, the possibility of obtaining immunotropic food ingredients on the basis of destruction products of LAB cell walls by the application of autolysis and enzymatic hydrolysis is considered. Due to the autolytic changes in bacterial cells, it is possible to eliminate the need for primary destruction of bacteria with the use of physical methods of exposure. This can significantly reduce the number of technological operations, and, as a result, the cost of the ingredient.

The work does not foresee the use of aggressive chemical reagents, which is inadmissible in food technologies. As an enzymatic hydrolyzing factor, pancreatin is used. There are no systematic studies about the influence of pancreatin on the degradation efficiency of LAB autolysate in the literature.

\section{The aim and objectives of the study}

The aim of the work was the determination of the rational regimes of enzymatic degradation of LAB autolysate and the description of the resulting products as promising components of immunotropic food ingredients.

To achieve this aim, it was necessary to accomplish the following research tasks:

- to study the kinetics of autolytic changes during the storage of LAB biomass (BM);

- to determine the rational parameters of enzymatic degradation of LAB BM autolysate;

- to provide a description of the obtained low molecular weight degradation products using IR spectroscopy and gel chromatography methods.

\section{Materials of the research}

LAB BM, representing the sum of test cultures: Lactobacillus acidophilus, Lactobacillus delbrueckii subsp. 
bulgaricus, Bifidobacterium bifidum, Lactococcus cremoris, Streptococcus thermophilus with a concentration $5 \cdot 10^{9} \mathrm{CFU} / \mathrm{cm}^{3}$ was used for the study. The bacterial composition was kindly provided by the research and production enterprise "Ariadna", Odessa, (Ukraine) from its collection. Enzymatic degradation of biomass cell walls was performed with pancreatin treatment with a proteolytic activity 370 Un (Ternopharm, Ternopil).

The methods used in the study are described in [19].

\section{Results of the research of enzymatic degradation of BM LAB autolysate}

Investigation of autolytic changes in the LAB composition during storage showed that over time, there is a gradual decrease of the BM CFU. So, at the beginning of the experiment, the number of CFU was $5 \cdot 10^{9}$, and on the seventh day of exposure, it was already $7 \cdot 10^{4}$ (Fig. 1).

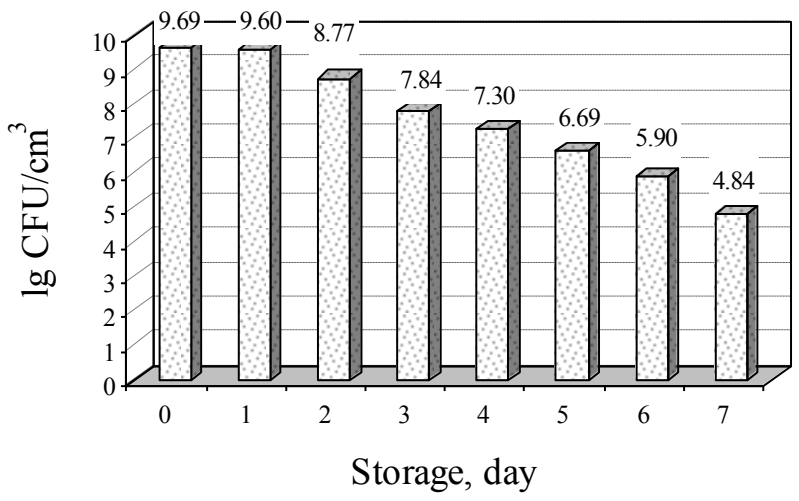

Fig. 1. Dynamics of changes in LAB CFU during storage

The substantiation of rational parameters of enzymatic hydrolysis (EH) of BM LAB autolysate. Fifteen experiments were carried out to determine the rational conditions of the $\mathrm{EH}$ of LAB BM autolysate in order to obtain the maximum amount of low molecular weight peptides (LMWP) having immunotropic properties [2]. Experimental conditions are given in Table 1. There are the design matrix of the experiment and also average (for three parallel) values of the results of the experiments CLMWP (yav), the estimated values (yp) by the regression equation and the relative errors $(\delta)$ between them.

The regression equation of the coded variables after the experiments was obtained using the least squares method and the sequential regression analysis implemented in the PLAN program [20,21]. The equation adequately (according to Fischer's criterion) describes the $C_{\text {LMWP }}$ dependence on $C_{\mathrm{E}}, C_{\mathrm{S}}$ and $\tau$ factors.

$$
\begin{aligned}
& y=0.454+0.0353 x_{1}+0.086 x_{2}+0.0896 x_{3}-0.0726 x_{1}^{2}- \\
& -0.2051 x_{3}^{2}+0.0525 x_{2} x_{3}
\end{aligned}
$$

where $x_{1}, x_{2}, x_{3}$ are the coded values of the factors $C_{\mathrm{E}}, C_{\mathrm{S}}$ and $\tau$, respectively, which are determined by the following ratios:

$$
\begin{aligned}
& x_{1}=\left(C_{\mathrm{E}}-10.05\right) / 9.95 ; \\
& x_{2}=\left(C_{\mathrm{S}}-40\right) / 30 ; \\
& x_{3}=(\tau-185) / 175 .
\end{aligned}
$$

Rational values of the factors $C_{\mathrm{E}}, C_{\mathrm{S}}$ and $\tau$ were determined using the obtained equation. These factors provide the maximum concentration of low molecular weight peptides $C_{\mathrm{LMWP}}=0.569 \mathrm{mg} / \mathrm{cm}^{3}$ in the hydrolysate medium: $C_{E}=12.5 \mathrm{mg} / \mathrm{cm}^{3}, C_{S}=70.0 \mathrm{mg} / \mathrm{cm}^{3}, \tau=245.6 \mathrm{~min}$.

\begin{tabular}{|c|c|c|c|c|c|c|c|c|c|}
\hline \multirow{3}{*}{$\begin{array}{c}\text { Exper- } \\
\text { iment } \\
\text { No. }\end{array}$} & \multicolumn{6}{|c|}{$\begin{array}{c}\text { Conditions of experiments in } \\
\text { dimension }\end{array}$} & \multicolumn{3}{|c|}{ Results } \\
\hline & \multicolumn{3}{|c|}{ natural } & \multicolumn{3}{|c|}{ coded } & \multirow{2}{*}{$\begin{array}{l}y_{a v}, \\
\mathrm{mg} / \\
\mathrm{cm}^{3}\end{array}$} & \multirow{2}{*}{$\begin{array}{l}y_{p}, \\
\mathrm{mg} / \\
\mathrm{cm}^{3}\end{array}$} & \multirow[b]{2}{*}{$\delta, \%$} \\
\hline & $\begin{array}{l}C_{E}, \\
\mathrm{mg} / \\
\mathrm{cm}^{3}\end{array}$ & $\begin{array}{l}C_{S}, \\
\mathrm{mg} / \\
\mathrm{cm}^{3}\end{array}$ & $\begin{array}{c}\tau, \\
\min \end{array}$ & $x_{1}$ & $x_{2}$ & $x_{3}$ & & & \\
\hline 1 & 0.1 & 10 & 10 & - & - & - & 0.019 & 0.018 & 3.83 \\
\hline 2 & 20 & 10 & 10 & + & - & - & 0.092 & 0.089 & 3.40 \\
\hline 3 & 0.1 & 70 & 10 & - & + & - & 0.085 & 0.085 & 0.32 \\
\hline 4 & 20 & 70 & 10 & + & + & - & 0.159 & 0.156 & 1.97 \\
\hline 5 & 0.1 & 10 & 360 & - & - & + & 0.095 & 0.092 & 2.66 \\
\hline 6 & 20 & 10 & 360 & + & - & + & 0.163 & 0.163 & 0.04 \\
\hline 7 & 0.1 & 70 & 360 & - & + & + & 0.372 & 0.369 & 0.68 \\
\hline 8 & 20 & 70 & 360 & + & + & + & 0.439 & 0.440 & 0.24 \\
\hline 9 & 0.1 & 40 & 185 & - & 0 & 0 & 0.341 & 0.347 & 1.62 \\
\hline 10 & 20 & 40 & 185 & + & 0 & 0 & 0.412 & 0.417 & 1.24 \\
\hline 11 & 10.05 & 10 & 185 & 0 & - & 0 & 0.371 & 0.368 & 0.69 \\
\hline 12 & 10.05 & 70 & 185 & 0 & + & 0 & 0.545 & 0.540 & 0.83 \\
\hline 13 & 10.05 & 40 & 10 & 0 & 0 & - & 0.153 & 0.160 & 4.39 \\
\hline 14 & 10.05 & 40 & 360 & 0 & 0 & + & 0.335 & 0.339 & 1.17 \\
\hline 15 & 10.05 & 40 & 185 & 0 & 0 & 0 & 0.458 & 0.454 & 0.77 \\
\hline
\end{tabular}

Table 1

The design matrix of the experiment and the results of the dependence of the LMWP content in the hydrolysate medium on different enzymatic degradation conditions

More clearly, the nature of the influence of the factors $C_{\mathrm{E}}, C_{\mathrm{S}}$ and $\tau$ on the process of accumulation of low molecular weight peptides $C_{\mathrm{LMwP}}$ in the hydrolysate medium is evident from the graphical interpretation of the regression equation, which is shown in Fig. 2.

At the next stage, the molecular weight of protein nature substances of the hydrolysate medium was determined (Fig. 3) in order to detect the structural components of BM cell walls corresponding to the molecular weight of the compounds of the muramyl peptide series (up to 1,500 Da) [12].

The results of the IR spectroscopy of the sample obtained under the rational conditions of enzymatic hydrolysis are shown in Fig. 4.

In the IR spectrum of the hydrolysate medium, there is a series of intensive absorption bands that are characteristic for oscillations of certain specific functional groups and bonds, which are inherent in low molecular weight degradation products of peptidoglycans of bacteria cell walls. Thus, in the spectral region of $3,380-3,450 \mathrm{~cm}^{-1}$, there is a broad band, which indicates the presence of free amino groups. The band at $1,642 \mathrm{~cm}^{-1}$ corresponds to fluctuations of peptide bonds, at $1,155 \mathrm{~cm}^{-1}$ - pyranose glucose form, at $1,013 \mathrm{~cm}^{-1}$ $\beta$-glycoside bond [22]. 


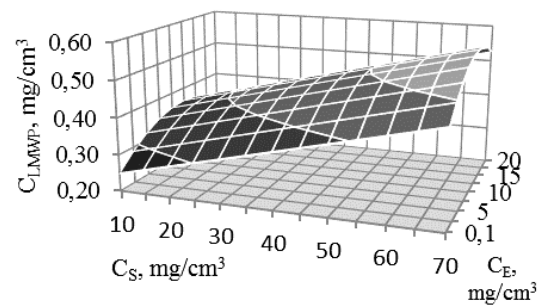

- $0,20-0,30=0,30-0,40=0,40-0,50=0,50-0,60$

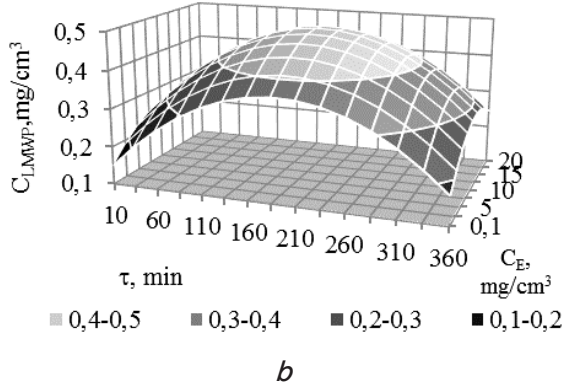

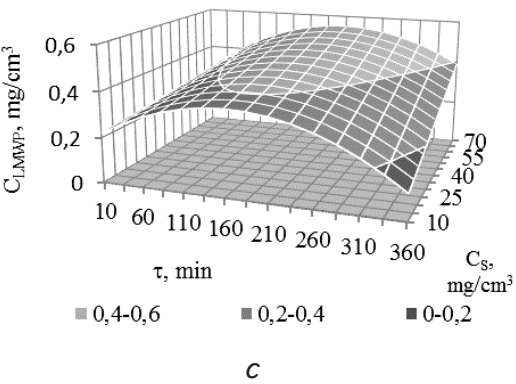

c

Fig. 2. Response surfaces of $C_{\mathrm{LMWP}}$ dependence on: $a-C_{\mathrm{E}}$ and $C_{\mathrm{S}}$ at $\tau=245.6 \mathrm{~min}$; $b-\tau$ and $C_{\mathrm{E}}$ at $C_{\mathrm{S}}=70.0 \mathrm{mg} / \mathrm{cm}^{3} ; c-\tau$ and $C_{\mathrm{S}}$ at $C_{\mathrm{E}}=12.5 \mathrm{mg} / \mathrm{cm}^{3}$

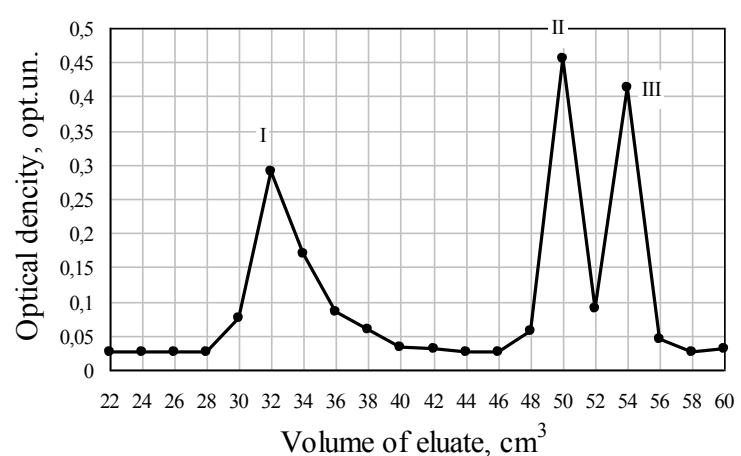

$a$

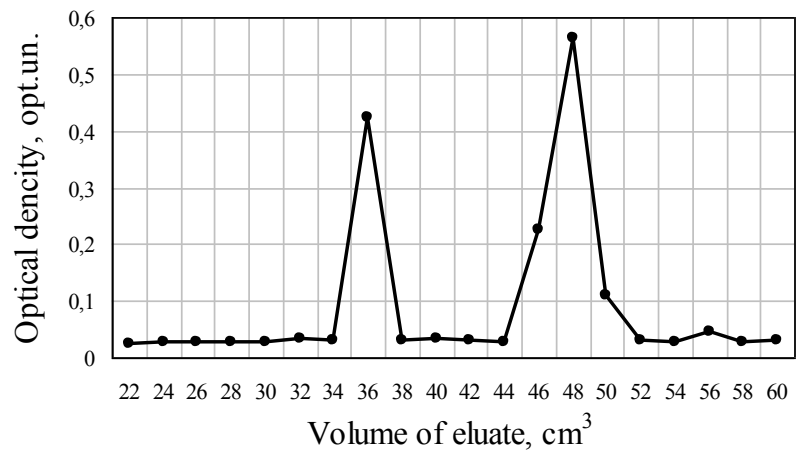

$b$

Fig. 3. Molecular weight distribution of LMWP of hydrolysate medium: a - gel chromatographic curve of markers; $b-g e l$ chromatographic curve of LMWP of hydrolysate medium

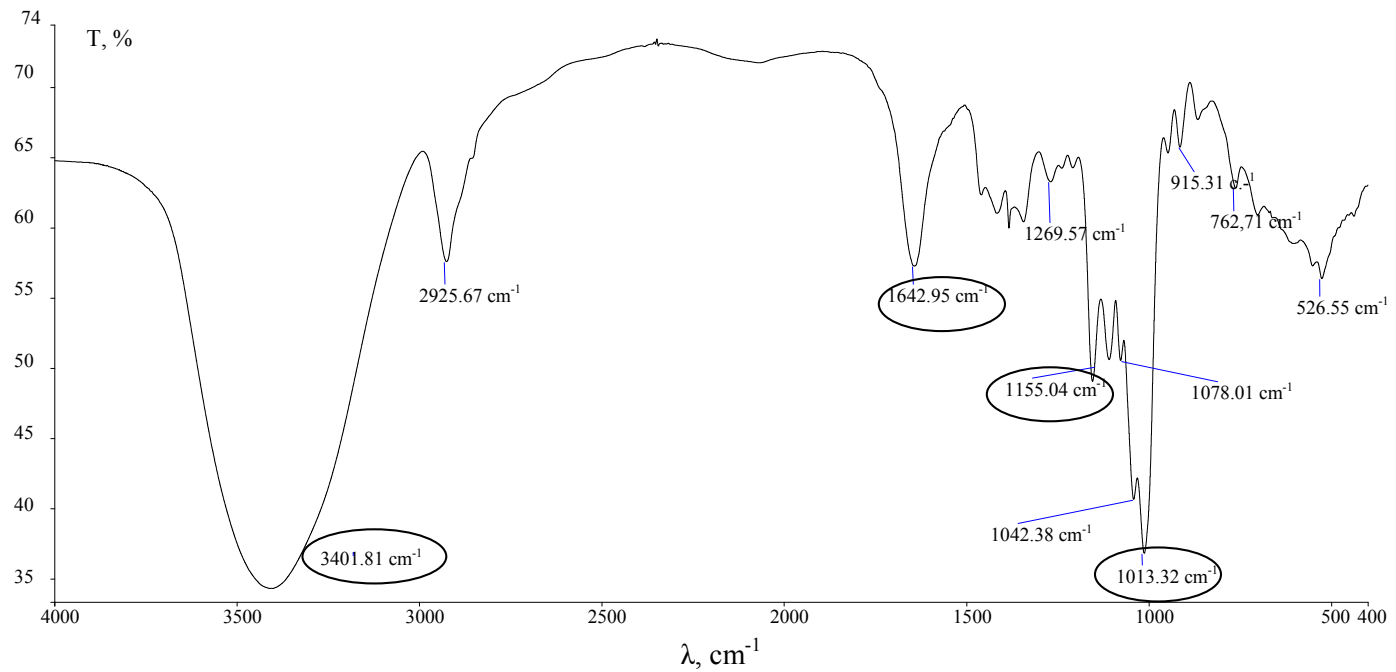

Fig. 4. IR spectrum of LMWP of hydrolysate medium

\section{Discussion of the results of investigations of enzymatic destruction of LAB BM autolysate}

Cell walls of microorganisms, especially gram-positive, including LAB, have high mechanical strength, which causes a significant obstacle to their disintegration. In order to overcome this problem, it was decided to use own resources of LAB, namely the presence of bacteriocin and autolysin of LAB cells in the culture fluid, which could contribute to the degradation of their cell walls. The results of studies on the autolysis process of the $\mathrm{LAB}$ composition have shown that exposure of LAB during 7 days significantly decreases the amount of biomass CFU (Fig. 1). This indicates the effectiveness of the autolytic processes, which can cause the destruction of the protective layer on the surface of bacteria, which is responsible for the mechanical strength of cells and resistance to biological degrading factors. Also, autolysis can provide the primary destruction of BM cells or their perforation.

Autolytic changes in the LAB biomass don't result in the production of low molecular weight target compounds, therefore, to achieve this objective the enzymatic hydrolysis of biomass autolysate with pancreatin was used.

The effectiveness of EH was controlled by the accumulation of target LMWP in the reaction medium. Constant parameters of $\mathrm{EH}$ were the temperature and $\mathrm{pH}$ of the me- 
dium. Variable factors were the concentration of the enzyme and substrate, the duration of the process. Such a number of variables involves a large number of experiments and considerable labor-intensive process.

As a result of experimental and design studies, the response surfaces of CLMWP dependence on the factors CE, $\mathrm{CS}$ and $\tau$ were constructed (Fig. 2). These parameters are almost in the middle of the variation intervals. Reduction of the amount of LMWP after reaching a maximum at 245.6 min can be explained by subsequent enzymatic hydrolysis, which causes the destruction of peptide bonds and the transformation of peptides to amino acids. As can be seen from the graphical dependence, an increase in the concentration of the enzyme in the reaction medium does not lead to an increase in the number of LMWP. Such tendency can be explained by the inhibition of the enzymatic process, which may be due to the accumulation of degradation products, or, in fact, the competition of a high number of enzymes in the reaction medium. The dependence of the LMWP accumulation on the concentration of the substrate is linear. The maximum LMWP accumulation occurs at a substrate concentration of $70.0 \mathrm{mg} / \mathrm{cm}^{3}$.

Samples of LMWPs obtained at the rational regimes of enzymatic destruction of biomass autolysate were investigated using gel chromatography and IR spectroscopy methods for a more in-depth study and identification of their structure. The results of gel chromatographic studies have shown that the molecular weight of the resulting LMWPs is within the range of 294-650 Da, which, in fact, corresponds to the molecular weight of MDP and GMDP (industrial preparation "Licopid") [6].

The samples, investigated by IR spectroscopy, were subjected to ion exchange chromatography in order to get rid of by-products of enzymatic hydrolysis. Such products can potentially affect the purity of the experiment and cause overlapping of the absorption bands of functional groups and chemical bonds of different nature. Absorption bands were marked in the IR spectrum of LMWPs corresponding to fluctuations of amino groups, peptide bonds, which, in fact, take place in the structure of peptides. Fluctuations of the pyranose glucose form, which is part of the muramic acid and $\mathrm{N}$-acetylglucosamine of peptidoglycan, MDP and GMDP, were also observed. There is an absorption band corresponding to the fluctuation of the $\beta$-glycoside bond, which binds the remains of the muramic acid and $\mathrm{N}$-acetylglucosamine in peptidoglycan and GMDP $[6,21]$.

The results of physicochemical studies of low molecular weight products of hydrolysis allow us to conclude that under the rational conditions of LAB biomass degradation, the main aim has been achieved. Obtained degradation products correspond to compounds of the muramyl peptide series having a powerful immunotropic effect. Since the aggressive toxic reagents have not been used in the LAB biomass degradation, the resulting product can be recommended as a nutritional ingredient for nutritional support of the population suffering from dysfunction of the immune system. In addition, a number of biologically active compounds such as LAB metabolites are contained in the hydrolysate composition except low molecular weight peptides $[1,5]$.
Thus, the proposed method of obtaining immunotropic fragments of LAB cell walls allows for a significant simplification of the process of their production, compared with existing methods [7, 12-14]. Namely, the autolysis use leads to the primary destruction of bacteria, which eliminates the operation of biomass degradation with the involvement of physical methods of influence. This contributes to reducing the number of technological operations and the absence of the need for additional equipment. The use of products of processing and metabolism of LAB biomass as food ingredients for oral administration allows avoiding a high degree of purification of the drug, as it is implemented in the production of pharmacological parenteral and nasal drugs.

The disadvantage of this study can be considered the specificity of selected modes relative to a specific composition of LAB, representing the sum of test cultures Lactobacillus acidophilus, Lactobacillus delbrueckii subsp. bulgaricus, Bifidobacterium bifidum, Lactococcus cremoris, Streptococcus thermophilus. When using monocultures of $\mathrm{LAB}$, or other LAB compositions, degradation results may differ from those given in this paper. The effectiveness of destruction will depend on the composition of the nutrient medium for the LAB cultivation, the conditions of cultivation, the characteristics of certain strains of microorganisms, the conditions of autolysis, etc.

The prospect of further research is the conduct of biomedical and clinical studies to determine the biological activity of the obtained product based on the LAB composition hydrolysate, which may be promising components of nutritional ingredients and dietary supplements.

\section{Conclusions}

1. The expediency of application of LAB BM autolysate to increase the effectiveness of enzymatic degradation of peptidoglycans in their cell walls has been proven. Accumulation of low molecular weight peptides in the enzymatic hydrolysis of biomass under rational parameters that was not subjected to autolysis is $0.260 \mathrm{mg} / \mathrm{cm}^{3}$, in the enzymatic hydrolysis of biomass that was subjected to autolysis is $0.569 \mathrm{mg} / \mathrm{cm}^{3}$.

2. The rational regimes of the enzymatic hydrolysis of the LAB composition $\left(C_{\mathrm{E}}=12.5 \mathrm{mg} / \mathrm{cm}^{3}, C_{\mathrm{S}}=70.0 \mathrm{mg} / \mathrm{cm}^{3}\right.$, $\tau=245.6 \mathrm{~min}$ ) have been determined with the involvement of the methods of mathematical planning of multifactorial experiments, which made it possible to significantly optimize and increase the efficiency of the work.

3. The belonging of LMWPs obtained at the rational conditions of enzymatic hydrolysis to immunotropic compounds of the muramyl peptide series has been proven by gel chromatography and IR spectroscopy methods. It is determined that the molecular weight of the obtained LMWPs is within the range of 294-650 Da, which, in fact, corresponds to the molecular weight of MDP and GMDP. In the IR spectrum of LMWPs, the absorption bands, which correspond to fluctuations of peptide bonds, pyranose form of glucose, $\beta$-glycoside bond, which in fact take place in the structure of peptidoglycans and MDP, are noted.

\section{References}

1. Kapustyan A., Cherno N. Immunological properties of the bacterial origin compounds // Food science and technology. 2016. Vol. 10, Issue 3. P. 19-28. doi: 10.15673/fst.v10i3.175 
2. MDP and other muropeptides - direct and synergistic effects on the immune system / Traub S., von Aulock S., Hartung T., Hermann C. // Journal of Endotoxin Research. 2006. Vol. 12, Issue 2. P. 69-85. doi: 10.1179/096805106x89044

3. MDP Up-Regulates the Gene Expression of Type I Interferons in Human Aortic Endothelial Cells / Lv Q., Yang M., Liu X., Zhou L., Xiao Z., Chen X. et. al. // Molecules. 2012. Vol. 17, Issue 12. P. 3599-3608. doi: 10.3390/molecules17043599

4. Matsui K., Ikeda R.Peptidoglycan in combination with muramyldipeptide synergistically induces an interleukin-10-dependent T helper 2-dominant immune response // Microbiology and Immunology. 2014. Vol. 58, Issue 4. P. 260-265. doi: 10.1111/13480421.12139

5. Kapustyan A. I., Cherno N. K. Prospects for using bioactive bacterial hydrolysates for nutritional supplementation of people with immune system disorders // Journal of Food Science and Technology. 2015. Vol. 9, Issue 2. P. 18-25. doi: 10.15673/2073$8684.31 / 2015.44263$

6. Andronova T. M., Pinegin B. V., Kozlov I. G. Likopid (GMPD) - sovremenniy otechestvenniy vysokoeffektivniy immunomodulyator. 4-e izd., dop. i pererab. Moscow, 2008. 24 p.

7. Proizvodnye muramildipeptida v klinike / Karaulov A. V., Kalyuzhin O. V., Likov V. F. et. al. // Aktual'nye voprosy klinicheskoy meditsiny. 2002. Vol. 2. P. 93-100.

8. The first ferrocene analogues of muramyldipeptide / Barišić L., Roščić M., Kovačević M., Semenčić M. Č., Horvat Š., Rapić, V. // Carbohydrate Research. 2011. Vol. 346, Issue 5. P. 678-684. doi: 10.1016/j.carres.2011.01.006

9. Shaphaev E. G., Tsyrenov V. Zh., Chebunina E. I. Dezintegratsiya kletok v biotekhnologii: ucheb. pos. Ulan-Ude, 2015. 96 p.

10. Humann J., Lenz L. L. Bacterial Peptidoglycan-Degrading Enzymes and Their Impact on Host Muropeptide Detection // Journal of Innate Immunity. 2008. Vol. 1, Issue 2. P. 88-97. doi: 10.1159/000181181

11. Kapustian A. Characterization of the bacterial origin immunotropic functional ingredients obtained through a physical impact // Scientific Messenger of LNU of Veterinary Medicine and Biotechnologies. 2017. Vol. 19, Issue 75. P. 13-18. doi: 10.15421/nvlvet7503

12. Gavrilin M. V., Sen'chukova G. V., Senchenko S. P. Vybor optimal'nyh usloviy polucheniya gidrolizatov molochnokislyh bakteriy termokislotnym sposobom // Himiko-farmatsevticheskiy zhurnal. 2007. Vol. 41, Issue 2. P. 54-56.

13. Izuchenie sostava preparata, poluchennogo na osnove gidrolizata molochnokislyh bakteriy / Senchenko S. P., Samoylov V. A., Gostishcheva N. M., Sen'chukova G. V., Gavrilin M. V. // Himiko-farmatsevticheskiy zhurnal. 2005. Vol. 39, Issue 3. P. 51-53.

14. Garanyan G. S., Hanferyan R. A., Oganesyan E. T. Himicheskoe obosnovanie i biologicheskoe issledovanie gidrolizata na osnove kul'tur molochnokislyh bakteriy // Himiko-farmatsevticheskiy zhurnal. 2010. Vol. 44, Issue 8. P. 46-49.

15. Molohova E. I., Sorokina Yu. V. Razrabotki otechestvennyh metabolitnyh probiotikov i ih standartizatsiya // Sibirskiy meditsinskiy zhurnal. 2011. Vol. 26, Issue 15. P. 29-33.

16. Glushanova N. A. Biologicheskie svoystva laktobatsill // Byulleten’ sibirskoy meditsiny. 2003. Issue 4. P. 50-58

17. Chapot-Chartier M.-P., Kulakauskas S. Cell wall structure and function in lactic acid bacteria // Microbial Cell Factories. 2014. Vol. 13, Issue Suppl 1. P. S9. doi: 10.1186/1475-2859-13-s1-s9

18. Stoyanova L. G., Ustyugova E. A., Netrusov A. I. Antimikrobnye metabolity molochnokislyh bakteriy: raznoobrazie i svoystva (obzor) // Prikladnaya biohimiya i mikrobiologiya. 2012. Vol. 48, Issue 3. P. 259-275.

19. Kapustian A., Cherno N. Obtaining and characteristic of the autolysate of lactic acid bacteria // EUREKA: Life Sciences. 2018. Issue 1. P. 24-31. doi: 10.21303/2504-5695.2018.00558

20. Matematicheskoe modelirovanie protsessov pishhevykh proizvodstv: handbook / Ostapchuk N. V. et. al.; ed. by Ostapchuk N. V. Kyiv: Vischa shkola, 1992. 175 p.

21. Matematicheskoe modelirovanie protsessov i apparatov himicheskih i pishchevyh proizvodstv: uch. pos. / Dvoretskiy D. S., Dvoretskiy S. I., Peshkova E. V., Temnov M. S. Tambov: Izd-vo FGBOU VPO «TGTU», 2014. 80 p.

22. Tarasevich B. N. IK-spektry osnovnyh klassov organicheskih soedineniy. Moscow, 2012. 54 p. 